\title{
35. 耳鼻科領域の立体レ線撮影
}

○斎藤春雄・北村溥之 - 東辻英郎 - 岸本娍司 - 松本 康（天理病院）

レ線像では身体内部の構造が平面として投影されるた め，これを元の立体的構造をもつたものにもどすには何 らかの工夫が必要である。昨今，耳鼻科領城では，前 後, 側面方向撮影, 断層撮影により頭の中で解剖学的知 識を駆使して立体に組立てる方法が一般的である。しか るに，日常われわれは 2 眼の視差を利用して立体視をし ているのであるから立体レ線撮影を行えば特に詳しいレ 線解剖の知識がなくても明確に病変を読影することがで きる。

立体レ線撮影はことさら新しいものではなく，既に， 前世紀にその方法が磼立されている. 断層撮影が出現 し，それが改良される過程で忘れ去られているが，最近 われわれは，これを耳鼻咽喉科領域のレ線診断に応用 し，その有用性を再認識した。一般に広く知られていな い理由は発表方法を欠くためと考元，第76回目日本耳鼻 咽喉科総会に展示により供覧した。

\section{立体レ線撮影法}

1）管球回転法 2）被写体移動法 3）被写体回転 法があるが 1)，2）方一般的で，且，撮影が容易であ る. 立体レ線撮影用の管球も考案されているが(1), 動き のない骨部の病変を診る耳鼻科領域では，普通の管球を 用いた撮影で十分こと足りる。回転角, 又は, 移動距離 は，物体を見るときの瞳孔間距離物体の距離を考慮して 決めれば良いが, 管球の回転角, 被写体の移動距離, 立 体視深度, 焦点深度の間には次の如き関倸がある(2) す なわち，管球回転角又は被写体移動距離を小さくすると 焦点深度が大きくなるが立体視効果が少ない管球回転 角又は被写体移動距離を大きくすると立体視効果は大き いが焦点哚度は浅くなる。最も効果的な立体像を得る範 囲については多くの理論值が出されているが，1）撮影 距離は被写体の厚さの10倍より小さいこと 2）管球移 動距離は撮影距離の市をを越えぬことが大方の一致すると ころである。

\section{立体視}

1) 裸眼によるもの（輻輳立体視 開散立体視）

2）光線反射屈折によるもの（反射立体鏡，プリズム立
体鏡，レンズ立体鏡）3）光の性質を利用したもの（補 色, 扁光）が主な方法である，1）は特別の器具を要し ないので便利であるが，立体視できるまでには訓練を要 する，その方法は藤原(3)の論文を参照されたい，われわ れ軽便な市販のプリズム式立体鏡を利用している。

\section{レ線立体測定}

耳鼻科領域では病変の部位と範围を知る目的でレ線を 撮ることが多い，又，複雑な骨組織に包含された器官を 扱つているため，病変を位置ずける標識にことかかず測 定を要する機会恃少ない，多くの測定法が提唱されてい るが煩頊であり臨床応用性に之しい 視差計算を利用し た岡田ら (4)の方法, すなわち, 撮影距離を $2 \mathrm{~m}$ と長くと ると Film 面より該当物体までの距離 $\fallingdotseq 10 \times$ 視差 $(\mathrm{mm})$ の式が実用性を残している。

\section{結 語}

立体レ線撮影を耳䁷科領域に応用し次の如き利点を認 めた，1） 2 枚の Film が補、合い影像が著しく鮮明と なる．2）平面像では重なり見えない構造物も明視化 される，3）読影が大変たやすく，位置の判定に良い， 4）断層撮影の代用ともなり線量を減じ得る.

以上の利点は複雑な解剖楼造を持つた耳鼻咽喉科領域 の診断に応用範囲が広く, 卒後教育, 実地医家での活用 を大いに推奖する。

質問・追加 向井貞三 (八尾市立病院). 1 . 左右の 写真を置きかえて右眼で右写真をそして左眼で左写真を 見た場合と本日展示のプリズムビュアーの如く視線交叉 の場合との違いは？2．航空写真加ら地図を作り等高 曲線を画く原理を応用すれば, 目的点の $x, \mathrm{y}, \mathrm{z}$ 座標を 算定できる。応答 斎藤春雄 (天理病院). プリズ 么立体鏡では左右逆に見えるのが欠点だが，フィルムを 逆に襄がえして置けば正常にみえる. 頭で逆転して考え る方が面倒でない，計測には種々方法が発表されている が，位置をみわける構造物が多く存在する耳鼻科領城の レ線では，あまり計測の実用性がないのではないか．測 定を厳密にする目的であ机ば断層が優る。 